\title{
The Eggplants Crop Technology Optimization by Grafting
}

\author{
Marian BOGOESCU ${ }^{1 *}$, Madalina DOLTU ${ }^{1}$ \\ ${ }^{1}$ The Institute of Research and Development for Industrialization and Marketing of Horticultural \\ Products, Intrarea Binelui, no.1A, sector 4,Bucuresti,042159 \\ *)corresponding author, e-mail: bogoescumarian@gmail.com
}

BulletinUASVM Horticulture 72(2) / 2015

Print ISSN 1843-5254, Electronic ISSN 1843-5394

DOI:10.15835/buasvmcn-hort:10314

\begin{abstract}
Soil fumigation has been an essential component of greenhouses crops since the 1960's. Growing vegetables without soil fumigants has remained a challenge, partially because of the lack resistance to many soil borne plant pathogens of the commercially acceptable eggplant cultivars produced through conventional breeding. In field production, crop rotation is important to prevent infestation with diseases and pests. However, crop rotation is rarely practiced in greenhouse production, which allows soil-borne pathogens and pests to accumulate, progressively reducing crop yields. Grafting cultivars with high quality and productivity on rootstocks that are resistant to the soil pests and diseases is a method known from years ago, which was improved and quickly spread in the last years. Therefore, the aim of this research was to evaluate the performance of the eggplant grafting on the some rootstocks, in greenhouse conditions. There have been determined and calculated the marketable yield, fruits quality, frequency and root galling index of soil-borne diseases and nematodes, in the experimental variants. Grafting was found to resulted in an increased marketable yield and significantly reduced the incidence of Verticillium dahliae and Fusarium oxysporum f. sp. melongenae.
\end{abstract}

Keywords: Fusarium oxysporum, marketable yield, Verticillium dahlia.

\section{INTRODUCTION}

In Romania, there are 1.480 ha of under glass protected crops (420 ha in heated and 960 ha in unheated greenhouses), as well as more than 5,000 ha under plastic. Biotic and abiotic factors in greenhouses offer ideal conditions for many pathogens, causing serious damages to greenhouse crops. Soil-borne pathogens are very destructive in vegetable crops and are one of the most serious factors limiting the farmer's income.

Crop rotation is rarely employed in greenhouse culture. The resulting accumulation of soil pathogens negatively affects the crops, requiring the adoption of soil disinfestation practices or other control methods (Gullino et al., 2003). Soilborne pathogens such as Verticillium dahliae and Fusarium oxysporum f. sp. melongenae may cause yield losses exceeding $60 \%$ in affected production areas (Bletsos et al., 2003). Before 2002, soil disinfection in Romanian greenhouses was usually achieved by sterilization with steam or application of methyl bromide; $107.72 \mathrm{t}$ of methyl bromide was applied in 2003 (Bogoescu et al., 2005).

Traditionally, greenhouses were built near power plants in the main towns, to use the hot water they produced for soil treatment and for heating. However, since 1995, the liberalisation of the energy market has greatly increased the cost of steaming for soil treatment. At present, energy accounts for $75 \%$ of the production costs for protected and heated crops. The increased energy costs have drastically reduced the greenhouse area being heated and disinfected by steam. In addition, methyl bromide was banned for plant protection (fumigation) applications in Romania in January 2005, in adherence to the Montreal Protocol (1997) because it is an ozone-depleting compound (Gov. Ordinance no. 89/1999 approved by Law No.159/2000). 
Eggplant (Solanum melongena L.), also known as aubergine, is one of the most popular vegetables in Romania. However, growing eggplants without soil fumigants is challenging, in part because commercially acceptable cultivars from conventional breeding programs lack resistance to many soil borne pathogens (Bausher and Chellemi, 2001). One possible method to reduce production losses is the use of grafted plants. Productive eggplant cultivars onto rootstocks that are resistant to soil pests and diseases have been done for many years and recent improvements in the methodologies have spread quickly. Joining a suitable cultivar scion to wild-type rootstock which has a robust root system and strong resistance to soil pests and diseases induces the tolerance features to less favorable conditions of soil and environmental (Oda,1993). However the most important result of eggplants grafting is the increased resistance to the soil diseases such as Fusarium, Verticillium or nematodes (Bogoescu et $a l ., 2005)$. This paper evaluates the performance of grafted eggplants grown in greenhouse conditions in Romania.

\section{MATERIALS AND METHODS}

Experimental plots of grafted eggplants were organized in the 2013 in an unheated greenhouse at the Research and Development Institute for Processing and Marketing of Horticultural Products in Bucharest. The eggplant hybrid "Aragon F1"(seed source-Hazera Genetics), which is widely cultivated in the south of the country, was grafted onto the resistant rootstocks "Torvum vigor"(seed source-Kaneko Seeds) and "Emperador F1"(seed source-Rijk Zwaan). The cultivar "Torvum vigor" is based on the vigorous Solanum torvum species which is used only as an eggplant rootstock. It has good resistance against Ralstonia (Pseudomonas) solanacearum, Verticillium spp., Fusarium spp. and nematodes, confers resistance to high temperatures to the scion and yields well in the extended eggplant culture cycle. "Emperador F1" is a hybrid of Lycopersicon hirsutum $\times L$. esculentum, with KVP resistance (i.e., resistant to Pyrenochaeta lycopersici, Didymella lycopersici, Verticillium spp., Fusarium spp.). It is a very vigorous rootstock producing abundant crops of large fruit. Since it is tolerant of low temperatures, responds consistently in varying conditions and is highly resistant to nematodes, being appropriate for cultivation of both tomatoes and eggplants.

Grafting was done semi-automatically by robot 'Helper Robotech GR-800CS' in the pilot greenhouse of the Institute. Seedlings were transplanted 28 days after grafting.

Three experimental variants $\left(300 \mathrm{~m}^{2}\right.$ each) were organized, divided into three replicates $(100$ $\mathrm{m}^{2}$ /experimental plot). The seedling transplant was performed on April 7, 2013. Grafted plants were planted at a density of 540 plants per plot, while the not grafted control was planted at a density of 720 plants per plot (grafted plants have a larger vigor and habitus than ungrafted ones).

$\mathrm{V} 1=$ Aragon $\mathrm{F} 1 \mathrm{x}$ Torvum vigor

$\mathrm{V} 2$ = Aragon F1 $\times$ Emperador F1

V3 = Aragon F1 (not grafted control)

The soil was naturally infected with pathogens by uninterrupted cultivation of tomatoes, eggplants, peppers and cucumbers since 1969, and had received no fumigation or other soil disinfection since 2001.

The infection of plants by Verticillium dahliae and Fusarium oxysporum f. sp. melongenae, which are particularly troublesome in eggplant production, was determined by visual inspection and in some cases by microscopic inspection of tissue samples. After a month since the transplant of seedlings up to the end of the eggplants crop, every two weeks the appearance and development of disease symptoms were assessed and recorded.

For each pathogen agent, percent disease incidence (I\%) and percent disease severity (S\%) was estimated based on the following formulas: I\% $=(n \times 100) / N$, where " $n$ " is the number of diseased plants, "N" is plants total number (infected plants+ healthy plants) and $S \%=\Sigma(\mathrm{I} \times \mathrm{f}) / \mathrm{n}$, where "i" refers to severity measured "f" refers to number of affected plants recording the same percent and "n" is the total number of diseased plants.

The resulted values were used to calculate the attack degree (as an expression of extending attack seriousness) using the following formula: $\mathrm{AD} \%=(\mathrm{S} \%$ x I \%) $/ 100$, where $\mathrm{AD} \%$ represents attack degree.

It was determined the influence of eggplants grafting on the marketable yield (kg) and fruit quality. Fruits quality was assessed according to the Romanian standard of quality for fresh fruits and vegetables, Eggplants SR 1423/2003, 
expressed as percentage of harvested fruits. Statistical analysis was performed by Duncan's test, at the p of $5 \%$.

\section{RESULTS AND DISCUSSION}

In the conditions of a natural infections of the soil by Verticillium dahliae and Fusarium oxysporum f.sp. melongenae, the grafting effect, led to a significant reductions in frequency of damaged eggplants (Tab. 1). Eggplants grown on the resistant rootstocks 'Torvum vigor' and 'Emperador F1' had much lower frequencies of both pathogens $(\% \mathrm{~F})$.

Eggplants grown on the resistant rootstocks 'Torvum vigor' and 'Emperador F1' had lower frequencies of both pathogens $(\% \mathrm{~F})$ than ungrafted eggplants. Disease severity and attack degree were registered also significantly lower values (Tab. 1). Between grafted eggplants on different rootstocks, the data did not show significant differences according to the Duncan test, at the $\mathrm{p}=5 \%$.

The results concerning the presence and severity of root galls induced by nematodes recorded at the end of the crop are presented in Tab. 2.

The eggplant grafting led to significant reduction of the presence of nematode galling on rootstock roots. At the same time, the root index of gales varied from $1.2-1.4$ for grafted eggplants up to 3.7 for non grafted eggplants. Data analysis confirms the tolerance effect of grafted plants to Meloidogyne spp (Oda, 1993).

The marketable yield varied significantly between grafted and non-grafted eggplants (Fig.1), although there was no significant difference between the two grafted variants.

The range of variation was relatively small between grafted variant: 65.8t/ha (Aragon F1 $\mathrm{x}$ Torvum vigor) and 64.9t/ha (Aragon F1 x Emperador F1). The not grafted eggplants variant yield (Aragon F1) harvest was only of 44.6t/ha, with over $15 \mathrm{t}$ less than the registered yield of grafted eggplants variant.

With regard to the quality of the eggplant fruit, the proportion of the first class fruit was significantly higher from the grafted plants than from the not grafted control plants, although there was no difference between the two rootstocks in the proportion of the first class fruit(Fig. 2).

The data analysis showed an improvement of commercial quality at grafted eggplants with over $19.6 \%$ first class fruits than with not grafted eggplants; the average of non grafted plants had a percentage of first class fruits of only $79.40 \%$.

\section{CONCLUSIONS}

- eggplants grafting onto 'Torvum vigor' or 'Emperador F1' rootstocks, reduced the

Tab. 1 Infection of eggplants grown in greenhouse soil, which was naturally infected with Verticillium dahliae and Fusarium oxysporum f. sp. melongenae

\begin{tabular}{ccccccc}
\hline \multirow{2}{*}{ Combinations (scion x rootstock) } & \multicolumn{3}{c}{ Verticillium dahliae } & \multicolumn{2}{c}{$\begin{array}{c}\text { Fusarium oxysporum f. sp. } \\
\text { melongenae }\end{array}$} \\
\cline { 2 - 7 } & $(\%) \mathrm{I}$ & $(\%) \mathrm{S}$ & $(\%) \mathrm{AD}$ & $(\%) \mathrm{I}$ & $(\%) \mathrm{S}$ & $(\%) \mathrm{AD}$ \\
\hline 'Aragon F1' x 'Torvum vigor' & $0.82 \mathrm{a}^{1}$ & $4.42 \mathrm{a}$ & $0.03 \mathrm{a}$ & $0.64 \mathrm{a}$ & $3.46 \mathrm{a}$ & $0.02 \mathrm{a}$ \\
\hline 'Aragon F1' x 'Emperador F1' & $0.87 \mathrm{a}$ & $4.69 \mathrm{a}$ & $0.04 \mathrm{a}$ & $0.58 \mathrm{a}$ & $3.13 \mathrm{a}$ & $0.02 \mathrm{a}$ \\
\hline 'Aragon F1' (ungrafted control) & $4.03 \mathrm{~b}$ & $29.01 \mathrm{~b}$ & $1.17 \mathrm{~b}$ & $5.42 \mathrm{~b}$ & $39.02 \mathrm{~b}$ & $2.11 \mathrm{~b}$ \\
\hline Tn each column, values followed by the same letter is not significantly different at the 5\% level of significance, using Duncan's test
\end{tabular}

Tab. 2 Effect of grafted eggplants on root index and on average of percentage of infected plants assessed on all plants collapsed and still living at the end of the trial

\begin{tabular}{|c|c|c|}
\hline \multirow{2}{*}{ Combinations (scion $\mathrm{x}$ rootstock) } & \multicolumn{2}{|c|}{ Meloidogyne sp. } \\
\hline & Root index $(0-5)$ & Infested eggplants(\%) \\
\hline Aragon F1 x Torvum vigor & $1.2 \mathrm{a}$ & $9.6 \mathrm{a}$ \\
\hline Aragon F1 x Emperador F1 & $1.4 \mathrm{a}$ & $10.9 \mathrm{a}$ \\
\hline Aragon F1 (ungrafted control) & $3.9 \mathrm{~b}$ & $36.7 \mathrm{~b}$ \\
\hline
\end{tabular}




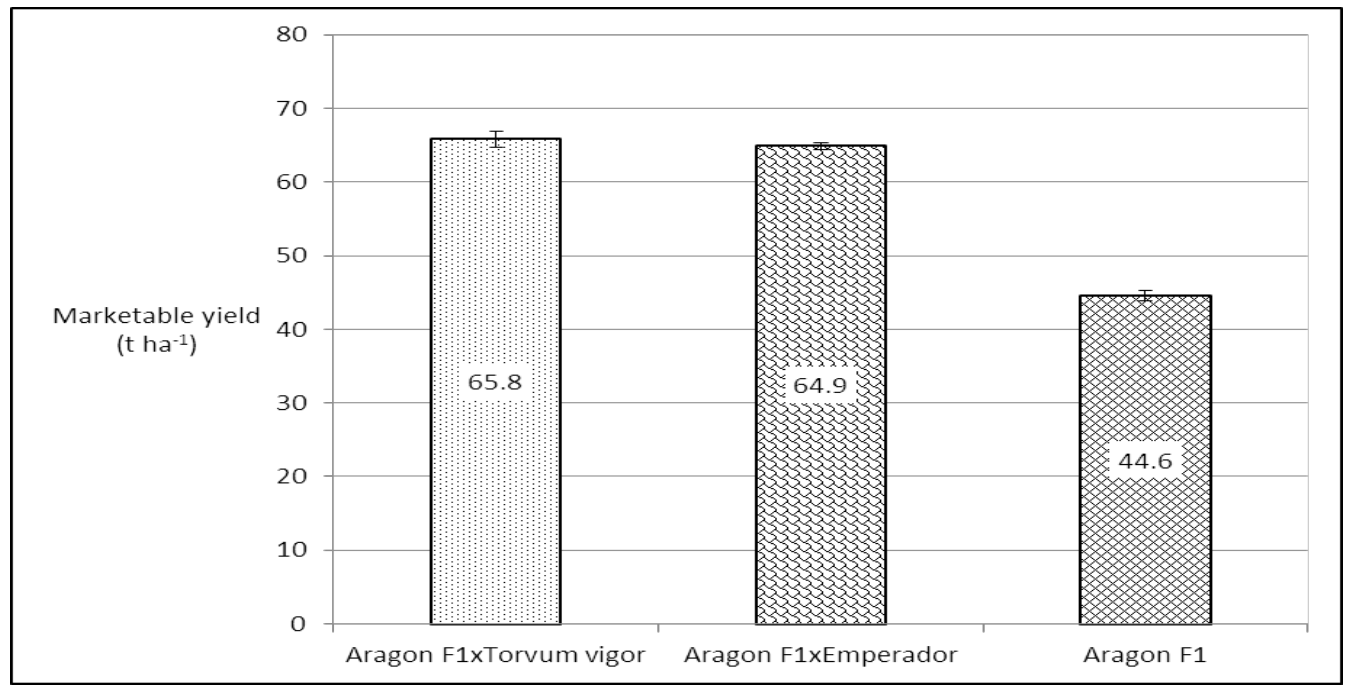

Fig. 1 Marketable yield ( $\mathrm{t} \mathrm{ha}^{-1}$ ) of greenhouse grown eggplant fruit from grafted and ungrafted plants grown in soil which was naturally infected with soil pathogens. The X-axis labels indicate scion x rootstock; the ungrafted control has no rootstock designated.

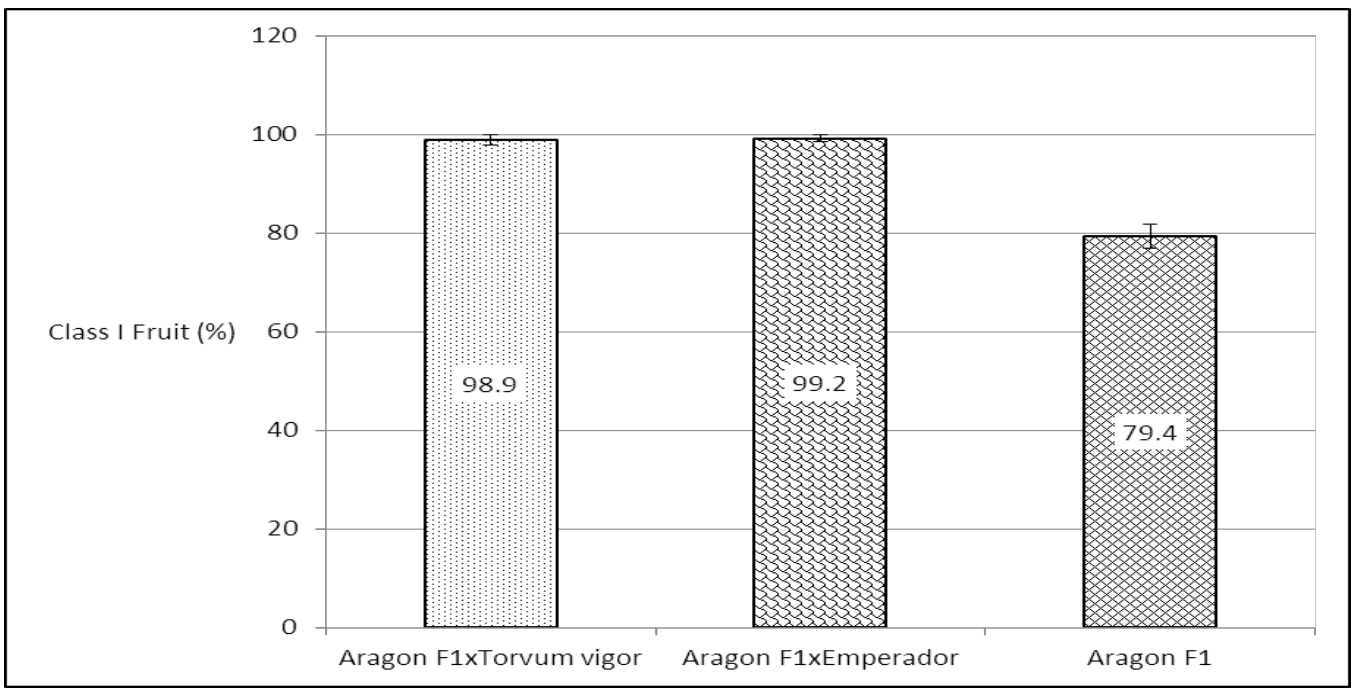

Fig. 2 Quality of greenhouse grown eggplant fruit grown on soil which was naturally infected with soil pathogens, using grafted and non-grafted plants, as represented by percentage of Class fruit harvested for each grafting treatment. The X-axis labels indicate scion x rootstock; the ungrafted control has no rootstock designated.

frequency and severity of infection with the soil borne pathogens (Verticillium dahliae and Fusarium oxysporum f. sp. melongenae ) and in the same time the frequency and root index of nematodes(Meloidogyne spp.).

- eggplants grafting increased marketable yield by as much as $21 \%$ while the proportion of high quality first class fruit which were harvested increased approximately $20 \%$.

Acknowledgements. The data presented in this paper were obtained during research funded from the Sectorial National Plane of Research respectively ADER project 1.2.5. "Reduction of production losses due to thermic, hydric and biotic stress from the eggplant cultures through the use of tolerant and/or resistant rootstocks".

\section{REFERENCES}

1. Bausher MG and Chellemi DO (2010). Performance of grafted tomatoes in open field trials at two locations in florida, Annual International Research Conference on Methyl BromideAlternatives and Emissions Reductions,77-1:77-2. 
2. Bletsos F, Thanassoulopoulos C and Roupakias D (2003). Effect of grafting on growth, yield and Verticillium wilt of eggplant. HortScience 38:183-186.

3. Bogoescu M, Gullino ML, Minuto A and Amadio A (2005). Alternatives to methyl bromide in Romanian protected crops. Acta Hort. (ISHS) 698:315-320.

4. Gov. Ordinance no. 89/1999 published in OM nr. 423/31 August 2009, approved by Law No.159/2000, art. 9 published in OM nr. 486/05 October 2000.
5. Gullino ML, Camponogara A, Gasparrini G, Clini C and Garibaldi A (2003). Replacing methyl bromide for soil disinfestations: The Italian experience and the implication for other countries.Plant Dis. 87:1012-1021.

6. Oda M (1993). Present state of vegetable production using grafted plants in Japan. Agr. Hort.68:442-446. 